\title{
FLIPPING PERCEPTIONS, ENGAGEMENTS AND REALITIES: A CASE STUDY
}

\author{
Dr. Nihan Kutahnecioglu INAN \\ ORCID: https://orcid.org/0000-0002-6071-2347 \\ Muscat, Oman \\ Kavitha BALAKRISHNAN \\ ORCID: https://orcid.org/0000-0003-4446-2656 \\ Faculty of Applied Communication, Multimedia University \\ Melaka, Malaysia \\ Dr. Muhammed REFEQUE \\ ORCID: https://orcid.org/0000-0002-3778-3585, \\ University of Madras \\ India
}

Received Date: 08/02/2018 Accepted Date: 31/07/2018

\section{ABSTRACT}

Flipped learning is considered as an active and constructivist teaching and learning approach to enhance the learning experience of both students and teachers. This research, conducted within the framework proposed by Jonathan Bergmann, explores the students' as well as teachers' perception of flipped learning. The study uses both quantitative and qualitative methods to collect data from the respondents. Separate questionnaires were used to collect the information from teachers and students, and a structured interview was conducted with teachers. Total of 56 students and 14 teachers from an undergraduate business program participated in this study, and all the respondents had experience in flipped learning. Results show both the students and teachers hold a positive perception towards flipped approach, and they consider this approach as an innovative way of teaching and learning. Study also identified the factors affecting the effectiveness of flipped classrooms and provides necessary recommendations for its successful implementation.

Keywords: Flipped learning, student engagement, personalized instruction, technology integration, peer assistance, collaborative learning, self-learning.

\section{INTRODUCTION}

Technology has brought about tremendous changes in classroom practices compelling the academic world to think beyond the traditional style of teaching and learning. The latest evidence of such change is the idea and wider acceptance of flipped learning (Al Rowais, 2016; Muldrow, 2013) which brought a paradigm shift in teaching practices across academic institutions (Gayathri \& Vijayarani, 2017).

Though there are various definitions provided by researchers on the 'flipped' concept, there is a common understanding on the very basic concept of flipped classrooms which is to flip conventional instructional approach, enable interactive lessons, allow accessibility of learning materials outside classrooms, analyze complex materials, resolve problems and encourage group or collaborative learning (Tucker, 2012; FindlayThompson and Mombourquette, 2014; Foldnes 2016; Nguyen et. al., 2015). Flipped learning also promotes technology enhanced learning which in turn would support flexible pedagogies (Al Rowais, 2016; 
Gordon, 2014). Flipped learning can help increase personalized contact hours between students and teachers, scaffold life-long learning and promote active engagement in the learning process (Bergman et. al., 2012).

This research is aimed at measuring the impact of flipped learning on student learning experience and analyzing the perception of teachers and students on flipped classrooms. The study also explores the role of technology in classroom delivery and student engagement.

\section{Significance of the Study}

The flipped classroom is recognized as an innovative and effective instructional approach that has changed from teacher-centered instruction to learner-centered learning practice (Hwang, Lai \& Wang, 2015; Al Rowais, 2016; Gayathri \& Vijayarani, 2017; Sivarajah, Curci, Johnson, Lam, Lee \& Richardson, 2018). The advancements in the information technology and communication brought about a paradigm shift in the teaching and learning practices by creating a learning environment conducive for wider engagement in the teaching and learning process (Lai, Hsiao \& Hsieh, 2018). Flipped learning, being the innovative (Hwang, Lai \& Wang, 2015; Gayathri \& Vijayarani, 2017; Sivarajah, Curci, Johnson, Lam, Lee \& Richardson, 2018) and constructive approach, is widely used in schools (LaFee, 2013) and higher educational institutions around the globe.

Though it has become a widely used approach worldwide, there is still scope for more researches to analyze the perceptions of staff and students on this approach, and to measure the impact of flipped learning on various aspects of student learning experiences such as student engagement, individual attention, technology integration, peer assistance, collaborative learning and self-learning. The demand for such a research is very high specifically in the context of Gulf region, as the GCC countries are showing highest trends in the technological advancements (Kostopoulos, 2003) and the educational institutions are continuously trying to be on par with latest trends in the field (Rowais, 2016). In order to enhance the economic diversification initiatives of gulf countries, the education sector became the focus in the developmental plan since 1990s (Weber, 2011), and was regarded as a national priority which the objective to provide qualitative education. Oman, one of the emerging economies in Gulf region is giving laudable priority for higher education. Thanks to its national education program, Oman has achieved a remarkable progress in the education sector with a record of 718,948 students attended the schools in 2014 compared to 900 students in 1970 (Ministry of Finance, 2016).

With the advancement of technology in the country, the educational institutions are also adopting latest teaching and learning practices to maintain their global standards and compete with other developed nations on academic platform. There are few studies available (Lane-Kelso, 2014; Lane-Kelso, 2015) on flipped learning in the context of Oman, but more needs to be done to provide a comprehensive analysis of this approach. As mentioned by Terry (n.d), the gaps in the research shows that the educational institutions in Oman are yet to embrace the concept of flipped learning on a wider scale.

Outcomes of this study can be used to introduce the flipped learning approach across the country considering its potential in enhancing the learning experience of the students. Study findings and recommendations would help educational institutions to make policy changes related to teaching and learning.

\section{THEORETICAL BACKGROUND}

Flipped learning is one of the latest teaching approaches that brought a huge impact on the student learning. It empowers the teachers to introduce various practices appropriate for each student (McLaughlin et al., 2014), and it has become "the most emphasized and innovative teaching strategies in recent years" (Hwang, 
Lai \& Wang, 2015). Present decade witnessed a number of universities and higher educational institutions embracing this approach, and there has been growing numbers of researches on this area covering different dimensions (Arfstrom \& Network, 2013; Bergmann \& Sams, 2014; Roach 2014; Bart, 2014).

Flipped learning enables introduction of flexible pedagogy that caters to varied needs of students, and improves student participation and engagement in the learning activities and processes (Roehl, et al, 2013; Bergmann \& Sams, 2014). This facilitates 'learner empowerment' as teacher-student interaction is taking a new shape with an increased scope for student involvement. "As advances in IT uncovered significant potential for opening up higher education learning process" (Ryan \& Tilbury, 2013), flipped approach provides a big room for effective use of technology that would facilitate interactive delivery and access to learning resources at learners' own pace. Thus, technology enables the students a choice in how and where to access the learning materials (Gordon, 2014).

One of the widely prevalent misconceptions about flipped learning is that the flipped learning is all about the video created by a teacher that is watched by students at home (Sams \& Bergmann, 2013; Gayathri \& Vijayarani, 2017). Even though the videos are integral part of flipping the classrooms, they are not ends in themselves, but just a beginning in the long journey of flipping. The basic idea of flipped approach lies in the concept of making the materials available to students prior to classroom sessions for them to read and come to class with a given set of pre-knowledge about the subject to be discussed, and the classrooms are used for working further on the prior knowledge. Thus, flipped learning is broadly about "how to best use in-class time with students" (Sams \& Bergmann, 2013; Bergmann, Overmyer \& Wilie, 2011).

While addressing digital natives with limited attention span (Davis, 2009), breaking the classroom hours into different constructive activities is very vital for effective transfer of knowledge.

\section{Individual Attention}

As Sam and Bergmann (2013) pointed out, many teachers may not be utilizing their class timing effectively despite the efforts made to deliver the contents. This can be attributed to many reasons such as the failure to provide individual attention and guidance to students, engage the students in higher order thinking (Lai, Hsiao \& Hsieh, 2018) and differentiate the instruction styles to cater to varied learning styles. However, a flipped classroom gives an opportunity to overcome these challenges as the direct instruction is done through the video which is watched by students beyond the classrooms. This leads to more effective utilization of class hours as students practice what they learnt through the videos or materials provided previously (Gayathri \& Vijayarani, 2017). In this process, instructors would be able to provide individual attention to students, provide guidance and extra attention (LaFee, 2013) to struggling students and give advanced tasks to students who already mastered the contents.

An efficient teacher tries to give attention to all students in the classroom. A common mistake visible in many of the classes is that teachers tend to speak to a particular group of students who are active in the class, while other students getting no or comparatively lower attention. Engaging all the students into learning without having purposeful focus on few sets of students is the best way to ensure that learning takes place in the classroom objectively and free from any kind of intentional or unintentional discrimination. This kind of individualized instruction would create a platform for every student to achieve mastery over the subject and the given task (Cohen, Kulik, \& Kulik, 1982; Bloom, 1984), and utilize the advantage of giving each student necessary attention, encouragement and praise. Hence, the teacher can contribute to the students' self-concepts (Heathers, 1977). Unlike conventional classroom setting, flipped classrooms provide a platform for the teachers and students to establish a personal rapport and personalize their interactions (Nguyen et. al., 2015). Teachers move from their dominant position in the front to everywhere else in the class and oversees the tasks performed by the students. 
The empirical studies also show that the flipping allows the teachers to interact with individual students and listen to their opinions and concerns (Stone, 2012). Flipping classroom redefines the role of a teacher as a coach (Bergmann \& Sams, 2012), and one of the greatest advantages of this approach lies in its ability to create an atmosphere where the teacher is individually guiding the students (Bergmann et al., 2011) and ensuring that the learning is taking place. Therefore, FLIP can also be referred as Focusing on your Learners by involving them in the Process (Honeycutt \& Garret, 2014).

\section{Technology and Flipped Approach}

Technology has played a remarkable role in redefining the approaches to teaching and learning and a good number of research studies propagate employing technology in education as part of the pedagogy (Young \& Bush, 2004; Di Benedetto, 2005; Okojie, et al., 2006; Maitra, 2007; Edwards \& Mckinnel, 2007; Barnett \& Coate, 2004; Barnett \& Coate, 2005; Bart, 2014).

Students who enroll in higher educational institutions today are referred as "digital natives" (Prensky, 2001), and they are gifted with excellent IT skills (Gosling, 2009). Consequently, the role of technology in teaching and learning has become undeniable, and increased access to technology, information and digital media has brought about unprecedented technological integration in classroom practices (Prensky, 2001).

Although some scholars have contended that technology is not very essential in self-learning, it has an important role in presenting and sharing the contents with students via different platforms before class time (Hwang, Lai \& Wang, 2015). Technology also provides the opportunity to create a learner-centric, individualized and interactive learning environment which supports learning anytime anywhere at learners' convenience (Maitra, 2007; Francl, 2014; Lai, Hsiao \& Hsieh, 2018). The use of technology can improve teaching quality and facilitate the attainment of learning outcomes (Wishart \& Bleases, 1999). It also enables the teachers to meet the needs and expectations of different students with multiple learning styles (Bryant \& Hunton, 2000).

As the teaching and learning has undergone a massive transformation due to advancements in the technology (Edwards \& Mckinnel, 2007; Young \& Bush, 2004), the recent momentum gained by flipped approach can also be attributed to the development of information and technology. Contrary to conventional teaching methods (Lai, Hsiao \& Hsieh, 2018), flipped classrooms require a proper integration of technology into teaching practices. Hence, many researchers have defined the concept of flipped learning with reference to technology (Bergmann \& Sam, 2012; Szafir \& Mutlu, 2013; Findlay-Thompson \& Mombourquette, 2014). Technology possesses inevitable role in developing the materials and providing access to the students (Barnett \& Coate, 2004; Barnett \& Coate, 2005) in addition to enhancing learners' experience with regards to content delivery, student engagement, formative and summative feedback and learning assessment. Moreover, in technology enabled flipped classrooms, students would most definitely develop higher order thinking skills (Roehl, et al., 2013; Hwang, Lai \& Wang, 2015, Lai, Hsiao \& Hsieh, 2018). Hence, technology plays an integral role in adopting flipped learning approach and demands unprecedented technological integration to harness student engagement, create learner-centric, individualized and interactive learning environment. The use of technology also improves teaching quality, fulfills learning outcomes, and enables multiple learning styles by augmenting varied teaching and learning strategies to meet the needs and expectations of learners.

\section{Student Engagement}

Contemporary teaching and learning approaches are designed with an objective of maximizing student engagement in the learning process, as an engaged environment facilitates the achievement of learning outcomes (Brame, 2013). A proper engagement of the students is possible only if the teaching style is matched with students' learning style, and a mismatch of any kind would lead to lesser engagement and thereby poor learning experience (Borg \& Shapiro, 1996). This finding highlights the necessity of having a 
portfolio of teaching styles that is catered to varied learning styles of the students (Lage, Platt \& Treglia, 2000).

Flipped classroom is an innovative pedagogical approach that focuses on learner centered delivery style (Gilboy et al., 2015; Sivarajah, Curci, Johnson, Lam, Lee \& Richardson, 2018; Lee \& Choi, 2018) and enhances student engagement (Tucker, 2012) which has always been a challenge for educators (Klem \& Connell, 2004). Flipped classrooms transform the roles of teachers and students, and compel the teachers to come up with new plans (Jinlei, Ying \& Baohui, 2012). As flipped classroom revolutionized the way students receive information from educators (Roach, 2014), it paved the way for more student engagement in the learning process. More engagement in flipped classroom is enabled as the students use their classroom hours to deepen their understanding of the subject (Klem \& Connell, 2004) and apply the knowledge obtained prior to the class time. In a flipped classroom, as the teachers walk around interacting with students (Stone, 2012) students feel more engaged and attached to lessons taught.

\section{Peer Assistance and Collaborative Learning}

The academic world has long before started to give an important focus on peer assistance in learning as peer instruction leads to increased mastery of the subjects (Crouch \& Mazur, 2001). Scopes for peer assistance and collaborative learning in pedagogical planning have become wider in recent years with its ability in bringing learning gains (Rohrbeck et al., 2003) and effectiveness in enhancing student learning (Field et al., 2007; Cheng \& Walters, 2009).

Similarly, the concept of collaborative learning has also become a widely followed practice of learning. The term collaborative learning stands for a group of people who attempt to study together (Dillenbourg, 1999). It facilitates the learning as the students of various performance levels work towards a common academic goal (Gokhale, 1995). Collaborative learning also enables the students to listen to their peers, develop teamwork skills, discuss their problems (Laal et al., 2013) rather than merely listening to the teachers (Webb, 1982). Most importantly, students are encouraged to learn from each other, identify their mistakes and that of their peers and correct the mistakes (O"Donnell \& Dansereau, 1992).

The analysis of flipped classrooms will not be complete unless a reference is made to its potential in encouraging peer assistance and collaborative learning. Under the flipped classrooms, teachers spend less time talking to students, and students spend more time solving the problems individually or in groups, engaging in group discussions and facilitating peer instructions. Thus, if learning process is flipped, classrooms are available for peer collaboration (Francl, 2014) as the students collaborate and support each other (See \& Conry, 2014).

The traditional classroom setup makes the collaborative learning difficult, whereas the flipped and active classroom environment makes it more possible as it facilitates small group works (Baepler, et al., 2014; Roach, 2014), and peer instruction leads to a significant improvement in the student learning (Crouch \& Mazur, 2001). This argument is also supported by the research findings of Foldnes (2016) and Strayer (2012) that the flipped classroom with elements of collaborative learning is more effective than the traditional classroom practice. Thus, in a flipped classroom, students gain lower levels of subject specific skills outside the classroom and higher level skills with the support of their peers in the classroom (Brame, 2013). This collaborative environment further supports the students to seek help from their peers when they are facing difficulties in learning (Chen, Wang \& Chen, 2014).

\section{Self-learning}

Academic world has recently begun to focus on the research studies and teaching trends that support selflearning among the students (Zimmerman, 1990). Contrary to the conventional teacher-centric classrooms where students act just as the listeners without effective engagement in the learning process, the modern 
constructive approach to teaching requires the students to take responsibility of their own learning. The former creates a passive learning environment where the learning responsibility is not shared between the teachers and students. The contemporary improvements in the teaching and learning methodologies have redefined the classrooms as more student centric (Lai, Hsiao \& Hsieh, 2018) and active learning environment, and this shift promotes self-learning with a view to convert the students as lifelong and independent learners.

Flipped methodology of learning contributes to a positive change in student perception as they have a control over their learning since they are required to go through the materials before coming to class (McLaughlin et al. 2013), and this in turn enhances the ability of the students to learn from multiple sources (Enfield, 2013). He concludes that self-pacing opportunities provided by flipped environment leads to a higher percentage of self-efficacy in the learning. This finding is also supported another study which observed that flipped approach provided better control of learning in students (Butt, 2004).

\section{Research Methodology}

The broad objective of this study was to analyze the impact of flipped learning on student learning experience within the framework proposed by Bergman et. al. (2012) and to analyze the perception of both students and the teachers on flipped learning. The study used quantitative data collection method and includes two different questionnaires for teachers and students. First questionnaire focused on the perceptions of the students and covered the following areas namely student engagement, individual attention, level of understanding, classroom effectiveness, peer assistance and self-learning.

Student engagement provides an engaged environment which facilitates the achievement of learning outcomes (Brame, 2013) where the teaching style matches the students' learning style. Flipped classroom focuses on learner centered delivery style (Gilboy et al., 2015; Lee \& Choi, 2018) and enhances student engagement (Tucker, 2012) which deepens the understanding of the subject (Klem \& Connell, 2004). Flipped classroom facilitates constant monitoring and interaction with the teachers (Stone, 2012) for better student engagement. Individual attention and guidance provided during class time can enhance student engagement (Sam and Bergmann, 2013). A flipped classroom effectively utilizes contact hours where instructors provide individual attention to students, provide guidance and scaffold (LaFee, 2013) struggling students, and motivate performing students with challenging tasks by engaging them in higher order thinking (Lai, Hsiao \& Hsieh, 2018). This also provide teachers to personalize their instruction to meet the diverse needs of students and check on their understanding of the subject. This way teachers can also gauge the level of their class effectiveness. On the other hand, peer assistance is known to increase mastery of the subjects (Crouch \& Mazur, 2001), bring about learning gains (Rohrbeck et al., 2003) and enhance student learning effectiveness (Field et al., 2007; Cheng \& Walters, 2009). There is an increased interest to understand self-learning support among the students (Zimmerman, 1990). Effective engagement through constructive approach requires students to participate actively in the learning process and take responsibility of their own learning. The contemporary student centric approach promotes self-learning and envisions lifelong and independent learning.

The second questionnaire comprised eight close-ended questions on teachers' perceptions with regards to student engagement, classroom effectiveness, peer assistance, self-learning and role of technology in flipped approach. Likert scale was used for both the questionnaires (1: strongly agree, 2: agree, 3: neither agree nor disagree, 4: disagree, 5: strongly disagree). The questionnaire also included four open ended questions framed to collect general opinions of the participants on flipped approach, the advantages and limitations of the approach and challenges faced in flipped classrooms. 


\section{Sample of the Study}

The study focused on undergraduate business program students and lecturers. The higher semester students of the program (students who have completed their two years in the program) and lecturers teaching the modules for the business program are considered as the population of the study. A total of 56 responses were collected from students and 14 responses were collected from teachers through a mixed mode approach.

\section{Students' Perception of Flipped Learning}

SPSS software was employed to analyze the responses collected from 56 students. The analysis (Table 1) provided a positive representation of students' perceptions of flipped learning as most of them endorse the benefits associated with it.

Table 1. Mean score: Students' Response

\begin{tabular}{|c|c|c|c|c|c|}
\hline Responses to questions & $\begin{array}{l}\text { Strongly } \\
\text { Agree }\end{array}$ & Agree & $\begin{array}{l}\text { Neither } \\
\text { Agree nor } \\
\text { Disagree }\end{array}$ & Disagree & $\begin{array}{l}\text { Strongly } \\
\text { Disagree }\end{array}$ \\
\hline Student engagement in the classroom & 73.2 & 8.9 & 17.9 & 0 & 0 \\
\hline Individual attention/guidance to students & 63.6 & 14.5 & 21.8 & 0 & 0 \\
\hline $\begin{array}{l}\text { Understanding through involvement in } \\
\text { activities }\end{array}$ & 46.4 & 14.3 & 37.5 & 1.8 & 0 \\
\hline $\begin{array}{l}\text { Checking the level of understanding of the } \\
\text { students during the class }\end{array}$ & 50.9 & 7.3 & 41.8 & 0 & 0 \\
\hline Effective use of the class hours & 62.5 & 14.3 & 23.2 & 0 & 0 \\
\hline Learning from peers & 54.5 & 10.9 & 32.7 & 1.8 & 0 \\
\hline Becoming a self-learner & 48.2 & 14.3 & 37.5 & 0 & 0 \\
\hline
\end{tabular}

$82.1 \%$ of the respondents agreed they are more engaged in flipped classroom compared to conventional classrooms and $78.1 \%$ of respondents agreed that they get individual attention and guidance from their lecturers in flipped classrooms. An almost equal number of students $(76.8 \%)$ agreed class timings are effectively used in flipped classrooms. Similarly, $60.7 \%$ of students admitted involvement in activities during flipped learning scaffolds comprehension and knowledge gain. However, it is worth mentioning that $37.5 \%$ of students neither agree nor disagree to this statement, and $1.8 \%$ of respondents disagree. Even though the number of students who agree outnumbered those who disagree, this clearly indicates the need to properly plan the activities for students for them to benefit from the learning experience. When $65.4 \%$ of the responses agreed they learn from their peers in flipped classrooms, $32.7 \%$ of the respondents neither agree nor disagree, and $1.8 \%$ of the respondents disagree with the statement.

A slight majority of students (58.2\%) believed flipped classrooms provide aid in reviewing their level of understanding in the class. However, $41.8 \%$ of students were neutral in their responses. $62.5 \%$ students agreed flipped classrooms contribute to their self-learning skills, and $37.5 \%$ students neither agree nor disagree with this statement. 
In general, it is very obvious students have positive perception towards this approach and are aware of its potential benefits. However, lecturers need carefully plan the activities and align them to the learning outcomes. They also need to ensure all students clearly understand and realize the relationship between the activities involved and the learning outcomes. Similarly, collaborative activities in the classrooms must be enhanced as it leads to learning from peers, and the students should be encouraged to actively participate in the discussions and sharing of ideas. Thus, an effective flipped classroom involves well designed lesson plans, diligently planned classroom activities and positive involvement of students in the learning.

\section{Teachers' Perception of Flipped Learning}

Lecturers responded to eight closed-ended questions on their perception of flipped learning in various aspects. The questions were framed in line with existing literature especially related to benefits accrue flipped learning. The Teacher Responses are stated in Table 2 below.

Table 2. Mean score: Teacher Responses

\begin{tabular}{|c|c|c|c|c|c|c|}
\hline Responses to questions & $\begin{array}{l}\text { Strongly } \\
\text { Agree }\end{array}$ & Agree & $\begin{array}{l}\text { Neither Agree } \\
\text { nor Disagree }\end{array}$ & Disagree & $\begin{array}{l}\text { Strongly } \\
\text { Disagree }\end{array}$ & Mean \\
\hline
\end{tabular}

\begin{tabular}{lcccccc}
\hline $\begin{array}{l}\text { Student engagement in } \\
\text { learning }\end{array}$ & 57.1 & 14.3 & 21.4 & 7.1 & 0 & 4.21 \\
$\begin{array}{l}\text { Individual attention to } \\
\text { students }\end{array}$ & 53.8 & 30.8 & 15.4 & 0 & 0 & 4.38 \\
$\begin{array}{l}\text { Understanding through } \\
\text { involvement in activities }\end{array}$ & 71.4 & 21.4 & 0 & 7.1 & 0 & 4.57 \\
$\begin{array}{l}\text { Checking the level of } \\
\text { understanding of the students }\end{array}$ & 64.3 & 35.7 & 0 & 0 & 0 & 4.64 \\
$\begin{array}{l}\text { Effective planning and } \\
\text { handling of the classes }\end{array}$ & 35.7 & 42.9 & 14.3 & 7.1 & 0 & 4.07 \\
$\begin{array}{l}\text { Learning from others } \\
\begin{array}{l}\text { Making students more } \\
\text { responsible in self-learning }\end{array}\end{array}$ & 53.8 & 38.5 & 7.7 & 0 & 0 & 4.46 \\
$\begin{array}{l}\text { Role of technology in flipped } \\
\text { classroom }\end{array}$ & 76.9 & 15.4 & 7.7 & 0 & 0 & 4.28 \\
\hline
\end{tabular}

Most of the teachers' perceptions (Table 2) were positive and $71.4 \%$ of them agreed flipped approach facilitates more student engagement in learning process compared to traditional approach. Interestingly, $84.6 \%$ of the teachers mentioned flipped classrooms enable the lecturers to pay individual attention to students, and $92.8 \%$ of the participants agreed students' understanding of the subjects or topic is enhanced as they involve in various flipped learning activities. Moreover, all participants agreed flipped approach provided better assessment of students' level of understanding during the class. While $78.6 \%$ of the respondents mentioned flipped approach provided opportunities for more effective planning and handling of the classes, $92.3 \%$ of them mentioned students can learn from peers in a flipped classroom more than in 
a conventional classroom. $78.6 \%$ of the participants agreed flipped approach makes students more responsible in their learning and contributes to their self-learning.

\section{Analysis of Teachers' Responses in Interviews}

A structured interview was conducted with 14 lecturers with experience of employing flipped learning techniques in teaching business modules to undergraduate students. The first part of the interview uncovered the general opinion of the lecturers on the concept of flipped classrooms and their perception on the influence of flipped learning on students' engagement, classroom attention, level of understanding, collaborative and independent learning and accountability. Their responses, "flipped learning facilitates student learning", "provides opportunity for teachers to prepare and plan well...", "an innovative teaching practice", “...extraordinary experience", "creates an active classroom environment...”, contributes to the enhancement of student skills and knowledge", were positive in a way that all the participants perceive flipped learning as an innovative and effective practice that enhances student learning and improves the skills of both teachers and students. Respondents unanimously agreed flipped classrooms provided more time to focus on the higher level of learning as the students come to class with a basic/prior knowledge of the topic. This in turn, leads to more fruitful use of class time. On the other hand, when respondents were questioned on the challenges and limitations of this approach, they admitted that "one of the challenges faced in flipped classroom is the non-cooperation of students. If students don't go through the materials or contents provided, teacher will have to resort to conventional teaching", whereas some thought "success of flipped classroom depends on the student involvement. They should come to class prepared and ready to participate in classroom activities". Another participant believed that "in flipped classrooms, learning is ensured when they are constructed by the students. In order for this to happen, students should come to class with a given level of knowledge by going through the materials provided earlier. If they fail to do, entire purpose of flipping will be at risk". Hence, respondents were of the opinion that flipped classrooms can accomplish its goals only if the students take responsibility of their learning and come to class prepared.

The discussion on the advantages of flipped learning provided more insights on the potentials of the practice. According to the respondents, "one of the advantages of flipped learning is its ability to have learning responsibilities shared between teachers and students. Such sharing is vital for the successful flipping". In flipped classrooms, students get individual attention as the class progresses with the continuous involvement of students in different learning activities. Learning becomes more enjoyable, and student engagement is enhanced as the students can access the materials anytime and anywhere. One of the participants observed "flipping makes the teachers technologically savvy and more updated with recent pedagogical practices, as the teachers have to continuously try to design the lesson plans in more active and innovative manner". Another participant added "flipping seriously calls for a student-driven and student-focused learning which gradually builds the culture of self and life-long learning".

Interestingly, there were no major disadvantages mentioned by the participants. One of the most repeated disadvantages of the flipped classrooms, according to participants is extensive dependence on the technology. As one participant observed "flipped learning becomes difficult for the teachers and students if they are not integrated with technology". While another participant reflected "in a place where the technological literacy or access is limited, flipping will not be an ideal mechanism".

Discussion on challenges faced by faculties while flipping the module include technological interruptions, non-cooperation from students who are unprepared with the materials provided prior to the class, resistance from the students to engage in the activities during the class and managing a large number of students in a class. Thus, it becomes clear from the interview analysis that flipped approach is an innovative teaching and learning practice that adds more value to students' learning. However, the successful implementation of flipped practices depends on many factors such as access to technology, lesson plans by the teachers, readiness 
of students and teachers, cooperation of students and support provided to teachers in the form of training and workshops.

\section{CONCLUSION}

Technology has caused a paradigm shift in the educational sector and brought tremendous changes in the teaching and learning practices. Flipped learning, the result of such technological advancement is considered as an active learning approach that enhances overall teaching and learning experience of teachers and students. A number of educational institutions are adopting this practice, and several research studies are also available providing comprehensive analysis on its potential values and dimensions. This study, conducted within the framework provided by Jonathan Bergmann, one of the developers of this approach analyzed the students' and teachers' perceptions of flipped learning.

The results of the study propounded the benefits of flipped learning for both teachers and students. Teachers are able to provide individual attention and guidance to the students, and students are actively engaged in the learning process. In flipped classrooms, classroom hours are more effectively utilized where students take active role in learning and interacting. Hence, flipped approach can be considered as a transformative way of teaching and learning, which frees up the classroom time for different activities promoting collaboration and interaction (Howitt \& Pegrum, 2015). Students get to learn from their peers and teachers provide personalized instruction.

Although flipped classrooms contribute to the development of student autonomy, self-learning and learning engagement, the success of this practice depends on specific factors such as the preparation of a detailed and active lesson plans, cooperation in sharing and learning responsibility of students, and proper alignment of flipped materials to learning outcomes. Students must clearly be able to link the learning activities in the class to intended learning outcomes. To realize the intended objectives of flipped learning, educational institutions need to continuously educate both students and teachers about the potential benefits of this approach.

As this research focuses only on undergraduate students and teachers in a business program, there is a scope for future research covering the students and teachers of other specializations to draw general inferences. However, as the students generally depict common characteristics, findings of this study would provide an insight for higher educational institutions in their pursuit of implementing flipped approach.

\section{BIODATA and CONTACT ADDRESSES of AUTHORS}

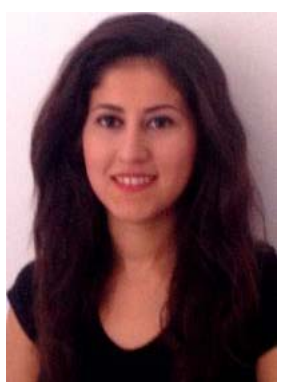

Nihan KUTAHNECIOGLU INAN gained her PhD degree in Business Administration in 2015. Dr. Nihan also completed her PG CERT in Higher Education in 2016. She has an experience of almost 8 years as an academician. Her professional philosophy is guided by continuous engagement in teaching pedagogy and discipline specific researches. Her academic interests are organizational behavior, cross-cultural studies in management, teaching and learning and flipped learning. Her current research study is accepted to be published in an international journal.

\section{Nihan KUTAHNECIOGLU INAN}

Address: Al Azaiba, Muscat, Oman

Phone: +96894071966

E-mail:nk.nihan@gmail.com 
Kavitha BALAKRISHNAN is a Principal Lecturer at Faculty of Applied Communication, Multimedia University, Malaysia. She has taught several English language and communication courses to foundation, diploma and degree students. She has provided business writing courses, in-house trainings and communication skills workshops focusing on writing, speaking, listening and grammar for participants from several government agencies, corporate clients and private organizations. She is also one of the authors of published books entitled Alpha English III, Traces 3, Quintessence and recently Avid.

Kavitha BALAKRISHNAN

Faculty of Applied Communication

Address: Multimedia University, Jalan Ayer Keroh Lama, 75450, Melaka, Malaysia

Phone: +6012690 5718; +6062523512

E-mail: kavitha.balakrishnan@mmu.edu.my

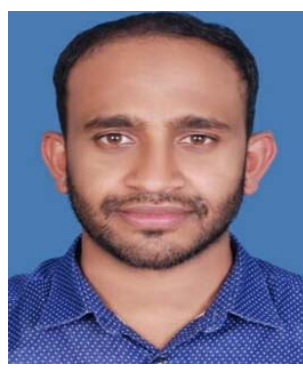

Muhammed REFEQUE is a PhD Scholar in University of Madras, India. He is pursuing academic research in Economics of Education. He has Masters in Economics from Pondicherry Central University. He has worked as Assistant Professor of Economics in The New College Chennai for two years. He has also worked in Middle East College, Oman for four years as faculty and academic coordinator. His areas of interest are economics of education, latest teaching practices, student employability, flipped learning and outcome based education. He has already published one article on Flipped Learning and has participated in many national and international conferences.

Muhammed REFEQUE

Economics, Research Scholar

Address: University of Madras, 600 005, Chennai, India

Phone: +919605291338

E-mail: raafeekwyd@gmail.com

\section{REFERENCES}

Al Rowais, A. (2016). 11 Flipped classrooms as a form of blended learning. Transforming Education in the Gulf Region: Emerging Learning Technologies and Innovative Pedagogy for the 21st Century, 171, 150.

Arfstrom, K. M., \& Network, P. D. F. L. (2013). A white paper based on the literature review titled A Review of flipped learning. Noora Hamdan and Patrick McKnight, Flipped Learning Network.

Baepler, P., Walker, J. D., \& Driessen, M. (2014). It's not about seat time: Blending, flipping, and efficiency in active learning classrooms. Computers \& Education, 78, 227-236.

Barnett, R., \& Coate, K. (2005). Engaging the Curriculum in Higher Education, Society for Research in Higher Education and Open University Press. McGraw-Hill House, England. ISBN 0, 335(21289), 1.

Barnett, R., \& Coate, K. (2004). Engaging the curriculum. McGraw-Hill Education (UK).

Bart, M. (2014). Blended and flipped: Exploring new models for effective teaching and learning. Faculty focus (Special Report). Madison, Wisconsin: Magna Publications. 
Bergmann, J., \& Sams, A. (2014). Flipped learning: Gateway to student engagement. International Society for Technology in Education.

Bergmann, J., \& Sams, A. (2012). Flip your classroom: Reach every student in every class every day. International Society for Technology in Education.

Bergmann, J., Overmyer, J., \& Wilie, B. (2011). The flipped class: Myths vs. reality. The Daily Riff, 1(4).

Bloom, B. S. (1984). The 2 sigma problem: The search for methods of group instruction as effective as one-to-one tutoring. Educational researcher, 13(6), 4-16.

Borg, M. O., \& Shapiro, S. L. (1996). Personality type and student performance in principles of economics. The Journal of Economic Education, 27(1), 3-25.

Brame, C. J. (2013). Flipping the classroom. Vanderbilt University. Center for teaching. Retrieved from https://cft.vanderbilt.edu/guides-sub-pages/flipping-the-classroom.

Bryant, S. M., \& Hunton, J. E. (2000). The use of technology in the delivery of instruction: Implications for accounting educators and education researchers. Issues in Accounting Education, 15(1), 129162.

Butt, A. (2014). Student views on the use of a flipped classroom approach: Evidence from Australia. Business Education \& Accreditation, 6(1), 33.

Chen, Y., Wang, Y., \& Chen, N. S. (2014). Is FLIP enough? Or should we use the FLIPPED model instead?. Computers \& Education, 79, 16-27.

Cheng, D., \& Walters, M. (2009). Peer-Assisted Learning in Mathematics: An Observational Study of Student Success. Australasian Journal of Peer Learning, 2(3), 23-39.

Cohen, P. A., Kulik, J. A., \& Kulik, C. L. C. (1982). Educational outcomes of tutoring: A meta-analysis of findings. American educational research journal, 19(2), 237-248.

Crouch, C. H., \& Mazur, E. (2001). Peer instruction: Ten years of experience and results. American journal of physics, 69(9), 970-977.

Davis, B. G. (2009). Tools for teaching. John Wiley \& Sons.

Di Benedetto, O. (2005, June). Does technology influence teaching practices in the classroom? In National Educational Computing Conference 2005 Conference Philadelphia, PA. Retrieved June (Vol. 1, p. 2006).

Dillenbourg, P. (1999). What do you mean by collaborative learning? Collaborative-learning:Cognitive and computational approaches, 1, 1-15.

Edwards, A., \& McKinnell, S. (2007). Moving from dependence to independence: the application of elearning in higher education. Learning, Teaching and Assessing in Higher Education: Developing Reflective Practice, 68.

Enfield, J. (2013). Looking at the impact of the flipped classroom model of instruction on undergraduate multimedia students at CSUN. TechTrends, 57(6), 14-27. doi:10.1007/s11528-013-0698-1

Field, M., Burke, J. M., McAllister, D., \& Lloyd, D. M. (2007). Peer assisted learning: a novel approach to clinical skills learning for medical students. Medical education, 41(4), 411418.

Findlay-Thompson, S., \& Mombourquette, P. (2014). Evaluation of a flipped classroom in an undergraduate business course. Business Education \& Accreditation, 6(1), 63-71. 
Foldnes, N. (2016). The flipped classroom and cooperative learning: Evidence from a randomised experiment. Active Learning in Higher Education, 17(1), 39-49.

Francl, T. J. (2014). Is Flipped Learning Appropriate?. Journal of Research in Innovative Teaching, 7(1).

Gayathri, H., \& Vijayarani, K. (2017). Flipping: A strategy for efficient learning in today's classroom. International Journal of Pedagogical Studies, 5(1), 72-83.

Gilboy, M. B., Heinerichs, S., \& Pazzaglia, G. (2015). Enhancing student engagement using the flipped classroom. Journal of nutrition education and behavior, 47(1), 109-114.

Gokhale, A. A. (1995). Collaborative learning enhances critical thinking.

Gordon, N. (2014). Flexible pedagogies: Technology-enhanced learning. From the report series Flexible Pedagogies: Preparing for the Future. The Higher Education Academy, January. Online at: http://www. heacademy.ac.uk/resources/detail/flexiblelearning/flexiblepedagogies/tech_enhanced_learning/m ain_report (accessed 20 June 2014).

Gosling, S. (2009). Mixed signals. Psychology Today, 42(5), 62-71.

Heathers, G. (1977). A Working Definition of Individualized Instruction. Educational Leadership, 34(5), $342-345$.

Honeycutt, B., \& Garrett, J. (2014). Expanding the definition of a flipped learning environment. Faculty Focus.

Howitt, C., \& Pegrum, M. (2015). Implementing a flipped classroom approach in postgraduate education: An unexpected journey into pedagogical redesign. Australasian Journal of Educational Technology, 31(4). 458-469

Hwang, G. J., Lai, C. L., \& Wang, S. Y. (2015). Seamless flipped learning: a mobile technology-enhanced flipped classroom with effective learning strategies. Journal of Computers in Education, 2(4), 449473.

Jinlei, Z., Ying, W., \& Baohui, Z. (2012). Introducing a New Teaching Model: Flipped Classroom [J]. Journal of Distance Education, 4(8), 46-51.

Klem, A. M., \& Connell, J. P. (2004). Relationships matter: Linking teacher support to student engagement and achievement. Journal of school health, 74(7), 262-273.

Kostopoulos, G. K. (2003, May). E-government in the Arabian Gulf: a vision toward reality. In Proceedings of the 2003 annual national conference on Digital government research (pp. 1-7). Digital Government Society of North America.

Laal, M., Naseri, A. S., Laal, M., \& Khattami-Kermanshahi, Z. (2013). What do we achieve from learning in collaboration?. Procedia-Social and Behavioral Sciences, 93, 1427-1432.

LaFee, S. (2013). Flipped learning. The Education Digest, 79(3), 13.

Lage, M. J., Platt, G. J., \& Treglia, M. (2000). Inverting the classroom: A gateway to creating an inclusive learning environment. The Journal of Economic Education, 31(1), 30-43.

Lai, H. M., Hsiao, Y. L., \& Hsieh, P. J. (2018). The role of motivation, ability, and opportunity in university teachers' continuance use intention for flipped teaching. Computers \& Education.

Lane-Kelso, M. (2015). The Pedagogy of Flipped Instruction in Oman. Turkish Online Journal of Educational Technology-TOJET, 14(1), 143-150.

Lane-Kelso, M. (2014). Mobiles and Flipping in Oman. 
Lee, J., \& Choi, H (2018). Rethinking the flipped learning pre class: Its influence on the success of flipped learning and related factors. British Journal of Educational Technology. https://doi.org/10.1111/bjet.12618.

Maitra, P. (2007). Higher Education and Global Challenges. Saurabh Publishing House.

McLaughlin, J. E., Roth, M. T., Glatt, D. M., Gharkholonarehe, N., Davidson, C. A., Griffin, L. M. \& Mumper, R. J. (2014). The flipped classroom: a course redesign to foster learning and engagement in a health professions school. Academic Medicine, 89(2), 236-243.

McLaughlin, J. E., Griffin, L. M., Esserman, D. A., Davidson, C. A., Glatt, D. M., Roth, M. T., \& Mumper, R. J. (2013). Pharmacy student engagement, performance, and perception in a flipped satellite classroom. American journal of pharmaceutical education, 77(9), 196. doi: 10.5688/ajpe779196

Muldrow, K. (2013). Flipping the Classroom. Language, 28.

Nguyen, B., Yu, X., Japutra, A., \& Chen, C. H. S. (2016). Reverse teaching: Exploring student perceptions of "flip teaching". Active Learning in Higher Education, 17(1), 51-61.

O’Donnell, A. M., \& Dansereau, D. F. (1992). Scripted cooperation in student dyads: A method for analyzing and enhancing academic learning and performance. Interaction in cooperative groups: The theoretical anatomy of group learning, 120-141.

Okojie, M. C., Olinzock, A. A., \& Okojie-Boulder, T. C. (2006). The pedagogy of technology integration.

Prensky, M. (2001). Digital natives, digital immigrants part 1. On the horizon, 9(5), 1-6.

Roach, T. (2014). Student perceptions toward flipped learning: New methods to increase interaction and active learning in economics. International Review of Economics Education, 17, 74-84.

Roehl, A., Reddy, S. L., \& Shannon, G. J. (2013). The flipped classroom: An opportunity to engage millennial students through active learning. Journal of Family and Consumer Sciences, 105(2), 44.

Rohrbeck, C. A., Ginsburg-Block, M. D., Fantuzzo, J. W., \& Miller, T. R. (2003). Peer-assisted learning interventions with elementary school students: A meta-analytic review. Journal of Educational Psychology, 95(2), 240-257.

Ryan, A., \& Tilbury, D. (2013). Flexible Pedagogies: new pedagogical ideas. Higher Education Academy, London.

Sams, A., \& Bergmann, J. (2013). Flip your students' learning. Educational leadership, 70(6), 16-20.

See, S., \& Conry, J. M. (2014). Flip My Class! A faculty development demonstration of a flippedclassroom. Currents in Pharmacy Teaching and Learning, 6(4), 585-588.

Sivarajah, R. T., Curci, N. E., Johnson, E. M., Lam, D. L., Lee, J. T., \& Richardson, M. L. (2018). A Review of Innovative Teaching Methods. https://doi.org/10.1016/j.acra.2018.03.025.

Stone, B. B. (2012). Flip your classroom to increase active learning and student engagement. In Proceedings from 28th Annual Conference on Distance Teaching \& Learning, Madison, Wisconsin, USA.

Strayer, J. F. (2012). How learning in an inverted classroom influences cooperation, innovation and task orientation. Learning Environments Research, 15(2), 171-193. doi:10.1007/s10984-012-9108-4 
Szafir, D., \& Mutlu, B. (2013, April). ARTFul: adaptive review technology for flipped learning. In Proceedings of the SIGCHI Conference on Human Factors in Computing Systems (pp. 10011010). ACM.

Terry, C. How can we evaluate the effectiveness of ICT resources in maximizing student learning in Oman?.

Tucker, B. (2012). The flipped classroom. Education next, 12(1).

Webb, N. M. (1982). Group composition, group interaction, and achievement in cooperative small groups. Journal of Educational Psychology, 74(4), 475.

Yang, J., Yu, H., Chen, S. J., \& Huang, R. (2014). Strategies for smooth and effective cross-cultural online collaborative learning. Journal of Educational Technology \& Society, 17(3), 208.

Young, C. A., \& Bush, J. (2004). Teaching the English language arts with technology: A critical approach and pedagogical framework. Contemporary Issues in Technology and Teacher Education, 4(1), 122 .

Zimmerman, B. J. (1990). Self-regulated learning and academic achievement: An overview. Educational Psychologist, 25(1), 3-17. 